« Fāṣele-hā-ye jog̉rāfiyā̄î̀ dar ostān-e Horāsān-e Raḍavī, va eḤtelāf-e Huațt šomārī-ye Huațte ab kaf-e dast dar țavāyef-e moḤtalef-e sāken dar īn ostān ». Tahqīqāt-e joğrāfiyā'ì $, 79,1384$, pp. 107-127. [Distance géographique et variabilité génétique des dermatoglyphes dans diverses tribus du Hưrāsān]

\title{
Bernard Hourcade
}

\section{(2) OpenEdition \\ 1 Journals \\ Édition électronique \\ URL : http://journals.openedition.org/abstractairanica/11272 \\ DOI : $10.4000 /$ abstractairanica. 11272 \\ ISSN : 1961-960X \\ Éditeur : \\ CNRS (UMR 7528 Mondes iraniens et indiens), Éditions de l'IFRI}

\section{Édition imprimée}

Date de publication : 15 mai 2007

ISSN : 0240-8910

\section{Référence électronique}

Bernard Hourcade, « « Fāșele-hā-ye jog̉rāfiyāî dar ostān-e Horāsān-e Raḍavī, va ehtelāf-e hațț šomārîye hatț-e ab kaf-e dast dar țavāyef-e mohntalef-e sāken dar īn ostān ». Taḥqīqāt-e jog̉rāfıyāî, 79, 1384, pp. 107-127. [Distance géographique et variabilité génétique des dermatoglyphes dans diverses tribus du Horāsān] », Abstracta Iranica [En ligne], Volume 28 | 2007, document 490, mis en ligne le 18 septembre 2007, consulté le 25 septembre 2020. URL : http://journals.openedition.org/ abstractairanica/11272 ; DOI : https://doi.org/10.4000/abstractairanica.11272

Ce document a été généré automatiquement le 25 septembre 2020. 
« Fāṣele-hā-ye jog̉rāfiyā'ì dar ostāne Horāsān-e Raḍavī, va eȞtelāf-e Hatț šomārī-ye Hațț-e ab kaf-e dast dar țavāyef-e moḨtalef-e sāken dar ìn ostān ». Taḥqīqāt-e jog̀rāfiyā'̄i, 79, 1384, pp. 107-127. [Distance géographique et variabilité génétique des dermatoglyphes dans diverses tribus du Horāsān]

Bernard Hourcade

À partir de l'analyse des empreintes digitales de populations de quatre ethnies différentes du Horāsān, les AA. ont pu déterminer que les corrélations étaient fortes d'une génération à l'autre dans chaque communauté qui conserve par ailleurs son identité de ce point de vue et sa distance vis à vis des autres populations. Une étude plus méthodologique que donnant des informations sur les identités ethniques. 
INDEX

Thèmes : 15.1. Iran

\section{AUTEURS}

BERNARD HOURCADE

CNRS / Mondes iranien et indien - Paris 